\title{
Ergonomic risk assessment with DesignCheck to evaluate assembly work in different phases of the vehicle development process
}

\author{
Winter Gabriele ${ }^{\mathrm{a}}$, Schaub Karlheinz G. ${ }^{\mathrm{a}}$, Großmann Kay ${ }^{\mathrm{b} ;}$ Laun Gerhard ${ }^{\mathrm{b}}$, Landau Kurt ${ }^{\mathrm{a}}$ and Bruder \\ Ralph $^{\mathrm{a}}$ \\ ${ }^{a}$ Institute of Ergonomics, Darmstadt University of Technology, Petersenstr. 30, D-64287 Darmstadt, Germany \\ ${ }^{b}$ Dr.-Ing. h.c. F. Porsche AG, Porscheplatz 1, 70435 Stuttgart-Zuffenhausen, Germany
}

\begin{abstract}
Occupational hazards exist, if the design of the work situation is not in accordance with ergonomic design principles. At assembly lines ergonomics is applied to the design of work equipment and tasks and to work organisation. The ignoring of ergonomic principles in planning and design of assembly work leads to unfavourable working posture, action force and material handling. Disorders of the musculoskeletal system are of a common occurrence throughout Europe. Musculoskeletal disorders are a challenge against the background of disabled workers. The changes in a worker's capability have to be regarded in the conception of redesigned and new assembly lines. In this way ergonomics becomes progressively more important in planning and design of vehicles: The objective of ergonomic design in different stages of the vehicles development process is to achieve an optimal adaptation of the assembly work to workers. Hence the ergonomic screening tool "Design Check" (DC) was developed to identify ergonomic deficits in workplace layouts. The screening-tool is based on the current ergonomic state of the art in the design of physical work and relevant EU legal requirements. It was tested within a federal German research project at selected work stations at the assembly lines at Dr.-Ing. h.c. F. Porsche AG / Stuttgart. Meanwhile the application of the screening-tool DC is transferred in other parts of the Porsche AG, Stuttgart. It is also realized as an ergonomic standard method to perform assembly work in different phases of the vehicle development process.
\end{abstract}

Keywords: Risk assessment, assembly work, musculoskeletal disorders

\section{Introduction}

At assembly lines vehicle geometry is responsible for imposed working postures in the form of (lateral) bending and twisting of the trunk and extension of the arms. Other factors can include the need to apply strong forces, unfavorable load-handling situations and extreme joint angles, in some cases aggravated by heavy stress on the finger-hand-arm system from application of strong action forces and repetitive movements. Therefore the ergonomic screening tool DC was developed in a joint project of the Ergonomics Institute, Darmstadt University of Technology (IAD) and Porsche AG, Stuttgart, promoted by the German Federal Ministry of Technology [1].
The challenge was how to optimize assembly work in an early stage of the vehicle development process. The ergonomic discussion in the Porsche Improvement Process has led to integrate DC solutions which could usually be realized. In order to transfer the results from the former research project into a sustainable ergonomic development, PAP (Porsche Arbeitsplatz-Ergonomie-Prozess) was initiated. It is the aim of PAP to link ergonomics structures of the plants (corrective / reactive ergonomics) and the design center (conceptive / proactive ergonomics). Of most relevance is to feed back information of existing ergonomic deficits in the production to the design center. This enables the designers to improve the situation by either changing the product or the process. In 
general it should be aimed to solve ergonomic problems as early as possible in the design process as this is least expensive while offering a maximum of freedom for design solutions at the same time. An aim is to develop in the areas of production design / design of machines comprehensive model range standards for the data of PAP that allow to port ergonomic objectives and design requests between running product and production development (model immanent ergonomic structure as extended institutionalized PVP process) on the one side and on the other side model series expansion (sustainable ergonomic process).

\section{Method}

Focusing onto user populations rather than on individuals requires that anthropometric (e.g. stature) and physical (e.g. maximal force) human characteristics are regarded as a distribution functions instead of scalar values.

"Design Check" - a paper \& pencil method - covers the major aspects of human characteristics. DC was designed as a 2D chart with respect to anthropometry (working postures) and physiology / biomechanics (e.g. physical load). It offers a 2D chart that contains anthropometric workplace requirements on the vertical axis and physiological \& biomechanical workplace requirements on the horizontal axis (Figure 1). The area spanned up by the two axes is split up in green, yellow and red areas indicating - as demanded by the EU machinery directive - work situations that are recommended (green), not recommended (yellow) or to be avoided (red).

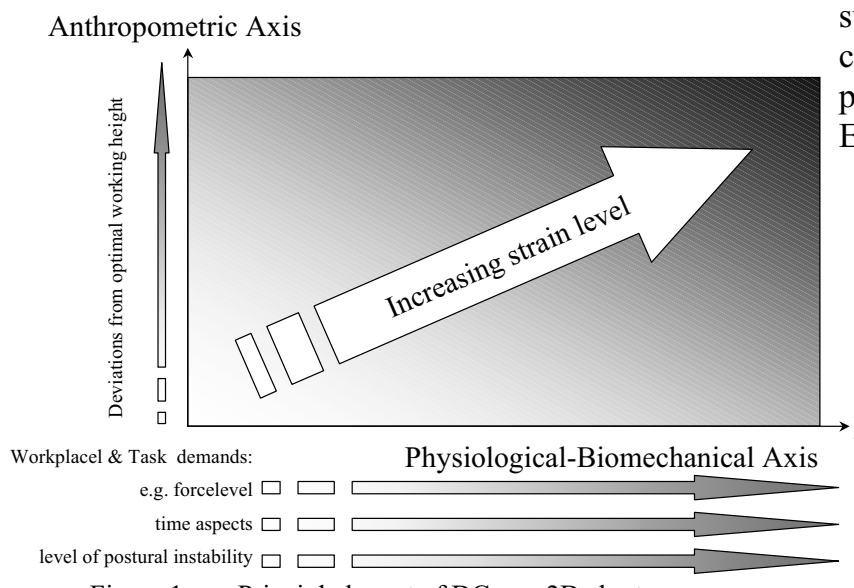

Figure 1: Principle layout of DC as a 2D chart
The anthropometric requirements cover working postures as well as visibility situations; the physiological \& biomechanical requirements are set up as a score of points indicating the total body load situation, the load situation of the hand arm system and loads generated by environmental conditions $[2,3]$.

\subsection{Risk assessment}

The machinery Directive obliges the designer to carry out risk assessments in an early design phase in order to ensure health and safety at work and good ergonomic design. The Machinery Directive is implemented by means of CEN standards. They give information on how to carry out a risk assessment. Table 1 offers the basic philosophy of a risk assessment according to EN 614 [4].

\section{Table 1}

Guidelines for a 3 zone risk assessment rating system with respect to EN 614

\begin{tabular}{lrl}
\hline \multicolumn{1}{c}{ zone } & \multicolumn{2}{l}{ Zone is represented by: } \\
\hline $\begin{array}{l}\text { Green } \\
\text { (low risk, }\end{array}$ & $\begin{array}{r}\text { zone } \\
\text { mended): }\end{array}$ & $\begin{array}{l}\text { An inherent safe approach; safe operation; ergo- } \\
\text { nomic principles fulfilled: for tasks of frequent }\end{array}$ \\
& $\begin{array}{l}\text { use for tasks of longer duration, with comfort } \\
\text { (well-being), e.g. zone of comfort reach.. }\end{array}$ \\
\hline $\begin{array}{l}\text { Yellow } \\
\text { (possible risk, not rec- } \\
\text { ommended): }\end{array}$ & $\begin{array}{l}\text { Ergonomic principles fulfilled for tasks of tem- } \\
\text { porary use, short duration. }\end{array}$ \\
$\begin{array}{l}\text { Red zone (high risk, to } \\
\text { be avoided): }\end{array}$ & $\begin{array}{l}\text { Ergonomic principles not fulfilled; } \\
\text { conditions, which can lead to unsafe operation.. }\end{array}$ \\
\hline
\end{tabular}

Remark: "Zone 1 is used for those tasks, which are required for the safe operation of the machine to ensure health and well-being for the operator. Zone 2 can be used for other tasks. NOTE: Those tasks being performed very seldom can be located in zone 3" (see EN 614-1, page 24).

\subsection{Evaluation of the physiological / biomechanical aspects of the workplace design}

The following table 2 shows DC elements of the physiological / biomechanical workplace evaluation. 
Table 2

DC elements of the physiological / biomechanical workplace evaluation

\begin{tabular}{|c|c|}
\hline & $\begin{array}{c}\text { Elements of the physiological / biomechanical } \\
\text { workplace evaluation }\end{array}$ \\
\hline Area I: & $\begin{array}{l}\text { Total body } \\
\text { Type of movement (low frequent, high frequent or static)Posture of the trunk and possible trunk supports } \\
\text { Posture of the arm, point of operation of forces or loads } \\
\text { Level of arm- / total body forces; exposure time and frequency of operation }\end{array}$ \\
\hline Area II: & $\begin{array}{l}\text { Hand-Arm-System } \\
\text { Type of movement (low frequent, high frequent or static) } \\
\text { Precision: accuracy level demanded to carry out movements or to operate control actuators } \\
\text { Anatomical axis of joints and their influence on and force direction and location of force exertion } \\
\text { Level of force exertion for the hand and fingers; exposure time and frequency of operation }\end{array}$ \\
\hline Area III: & $\begin{array}{l}\text { Aspects of and } \\
\text { Workplace Environment } \\
\text { Conditions of task execution. Access conditions to the workplace and to the area of operation } \\
\text { Visual clearance (is the working posture influenced by visual conditions), fits the viewing distance to the working task?, } \\
\text { (e.g. may close viewing distances be realized for precision work?) } \\
\text { Design of work equipment (e.g. tools, control actuators) and products } \\
\text { Influences of the physical work environment (e.g. climate, noise, illumination, vibration) [qualitative only] }\end{array}$ \\
\hline
\end{tabular}

\section{Sample}

The worker independent tool is used for designing layouts in early phases of the vehicle development process. DC was tested at the assembly lines of Porsche automobile industries (from the start Porsche Improvement Process, Stuttgart and Leipzig, Germany).

For example a complete assembly line (with eleven working stations, part A and B) was assessed with DC (working station 27 to 38 , concept provides 16 workers and 16 workplaces respectively), planned by Porsche Leipzig. Table 3 shows six stations as a part of the complete line with ergonomic potential. Line A was chosen for a detailed analysis of the conveyer to transport the vehicles (with and without turning).
The aim is to improve, with support of the DC, the ergonomic potential of different scenarios: recognizing the model specific ergonomic deficiencies in connection with different conveyer concepts (with and without turning).

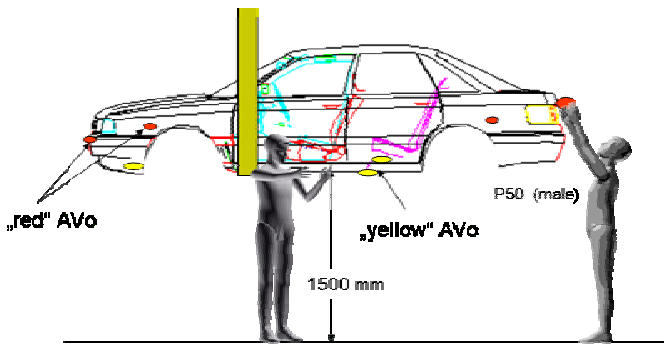

Figure 2: Set up covering, fixing and checking components manually (visualization with man model Anthropos, P50, different working heights, conveyer without turning)

For example the parameter body height: At first the workplaces have to be suitable for taller and smaller workers (for a huge majority of the general working population, e.g. 90\%). The sample shows a worker with an average height (P50, male) is able to reach the working position in the back of the car. 
Table 3

Assembly line (part A) with workplace evaluation with DC (conveyer without an with turning $90^{\circ}$

\begin{tabular}{|c|c|c|c|}
\hline $\begin{array}{l}\text { Assembly line A working } \\
\text { station }\end{array}$ & $\begin{array}{l}\text { Assembly task } \\
\text { (AVo) }\end{array}$ & $\begin{array}{l}\text { Evaluation with DC } \\
\text { (conveyer without turning) }\end{array}$ & $\begin{array}{l}\text { Evaluation with DC } \\
\text { (conveyer without turning 900) }\end{array}$ \\
\hline $\begin{array}{l}27(1 \text { worker }) \\
\text { Working height:(mm) } \\
1600-1900\end{array}$ & $\begin{array}{l}\text { Set up diverse supply lines (air, } \\
\text { brake), covering (heat), etc. }\end{array}$ & $\begin{array}{l}\text { Red(P5) } \\
\text { Yellow (P95) }\end{array}$ & $\begin{array}{l}\text { Yellow (P5) } \\
\text { Green (P95) }\end{array}$ \\
\hline $\begin{array}{l}28(1 \text { worker }) \\
\text { Working height:(mm) } \\
1900 \mathrm{~mm}\end{array}$ & $\begin{array}{l}\text { Put up sheet metal cover, set up } \\
\text { supply line (gasoline) }\end{array}$ & $\begin{array}{l}\text { Red (P5) } \\
\text { Yellow (P95 }\end{array}$ & $\begin{array}{l}\text { Red (P5) } \\
\text { Yellow (P95 }\end{array}$ \\
\hline $\begin{array}{l}29(1 \text { worker }) \\
\text { Working height:(mm) } \\
1000-1450 \mathrm{~mm}\end{array}$ & $\begin{array}{l}\text { Ventil mounting, supply lines at } \\
\text { wheel house, etc. }\end{array}$ & $\begin{array}{l}\text { Yellow (P5) } \\
\text { Green (P95 }\end{array}$ & $\begin{array}{l}\text { Yellow (P5) } \\
\text { Green (P95 }\end{array}$ \\
\hline $\begin{array}{l}30(1 \text { worker }) \\
\text { Working height:(mm) } \\
1900 \mathrm{~mm}\end{array}$ & $\begin{array}{l}\text { Put up covering panel, put up pump, } \\
\text { etc. }\end{array}$ & $\begin{array}{l}\text { Red (P5) } \\
\text { Yellow (P95 }\end{array}$ & $\begin{array}{l}\text { Yellow (P5) } \\
\text { Green (P95) }\end{array}$ \\
\hline $\begin{array}{l}31(1 \text { worker }) \\
\text { Working height:(mm) } \\
1900 \mathrm{~mm}\end{array}$ & Set up diverse supply lines & $\begin{array}{l}\text { Red (P5) } \\
\text { Yellow (P95) } \\
\end{array}$ & $\begin{array}{l}\text { Yellow (P5) } \\
\text { Green (P95) } \\
\end{array}$ \\
\hline $\begin{array}{l}32(2 \text { workers }) \\
\text { Working height:(mm) } \\
1900 \mathrm{~mm}\end{array}$ & $\begin{array}{l}\text { Set up clamping claw, pump, } \\
\text { heater matrix } \\
\text { Assembly tank (automatically) }\end{array}$ & $\begin{array}{l}\text { Yellow (P5) } \\
\text { Green (P95) } \\
\text { Green } \\
\text { (P5 - P5) }\end{array}$ & $\begin{array}{l}\text { Yellow (P5) } \\
\text { Green (P95) } \\
\text { Green } \\
\text { (P5 - P5) }\end{array}$ \\
\hline
\end{tabular}

Table 4

Assembly line (part A) with workplace evaluation with DC (conveyer without an with turning $90^{\circ}$

\begin{tabular}{|l|l|l|}
\hline $\begin{array}{l}\text { Results of the risk assessment with DC related } \\
\text { to } 16 \text { workplaces of the complete assembly } \\
\text { line }\end{array}$ & $\begin{array}{l}\text { Number of workplaces n (\%) } \\
\text { conveyor without turning } 0^{\circ}\end{array}$ & $\begin{array}{l}\text { Number of workplace } \mathrm{n}(\%), \text { conveyor turning 90 } \\
\text { (cycle time: 6-minute) }\end{array}$ \\
\hline Green & $6(38 \%)$ & $10(62 \%)$ \\
\hline Yellow & $1(6 \%)$ & $1(6 \%)$ \\
\hline Red & $9(56 \%)$ & $5(31)$ \\
\hline
\end{tabular}




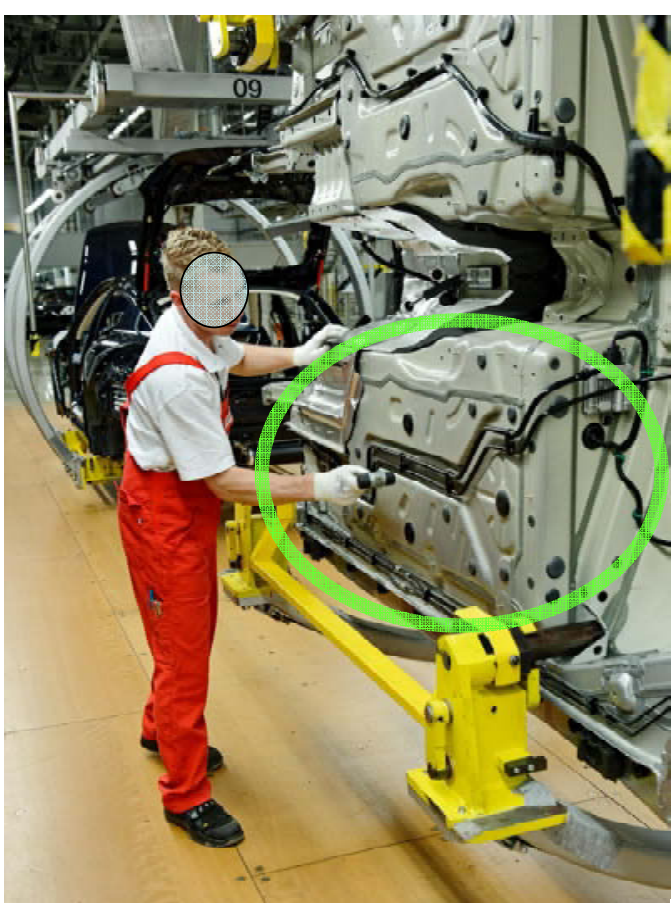

Figure 3: New assembly line -vehicle transport with conveyer (turning 90 degree)

Meanwhile the new assembly line is build up at Porsche Leipzig (Grossmann 2008).

\section{Results}

The studies at Porsche assembly lines show, how to perform methodical ergonomic work in early phases of the vehicle development process, for example to design vehicle prototype.
The application of DC allows analyzing and assessing stress at the assembly lines. In the result the ergonomic potential of the analysed working situation with the involved worker population at the assembly line is deduced. At least the application of the ergonomic risk assessment results in a continuous improvement process. Therefore DC is used as a key element in the so called "digital factory" which enables designers to decide the priority order of improvements. Various examples verify the reduced physical workload and decrease production time (e.g. MTM analyses show a range of 20 to nearly $40 \%$ ). Additionally the stability of production is increasing and the error ratio is reduced, too. The survey confirms the potential of ergonomically designed work processes with respect to legal requirements for ergonomic workplace design.

\section{References}

[1] Landau, K.; Luczak, H.; Keith, H.; Rösler, D.; Schaub, Kh.; Winter, G.: Bilanzierung Arbeitsgestaltung: Arbeitswissenschaftliche Konzepte, Erfolgsfaktoren und Transfermechanismen für die Entwicklung und Verbreitung ganzheitlicher Innovationsprozesse in der Güterproduktion und den produktionsnahen Dienstleistungen (AKTIV), Forschungsbericht für das Bundesministerium für Bildung und Forschung, Förderkennzeichen: 01HV0010, Bonn 2002

[2] Schaub, K.; Winter, G.: DesignCheck: ein Screeningverfahren zur Beurteilung körperlicher Belastungen. In: Der Orthopäde, 31. Jg., 10 (2002), S. 987 - 996.

[3] Winter, G.; Schaub, Kh.; Landau, K.; Großmann, K.; Laun, G.: DESIGN CHECK - ein Werkzeug zur ergonomischen Bewertung von körperlicher Arbeit bei Montagetätigkeiten. Angewandte Arbeits $\neg$ wissenschaft (1999), Nr. 160; S.16-35.

[4] EN 614-1: 2006/prA1:2008: Safety of machinery- Ergonomic design principles - Part 1: Terminology and general principles.

[5] Grossmann, K. DesignCheck - Transfer eines Planungstools für Arbeitsplätze. Präsentation Tagung "Gesundheit als Teil der Unternehmensstrategie. Ein Austausch zu Konzepten und Erfahrungen aus Theorie und Praxis". 01.12.2008 Darmstadt. 